DOI: https://doi.org/10.31933/dijms.v2i4

Received: 21 January 2021, Revised: 7 March 2021, Publish: 15 April 2021

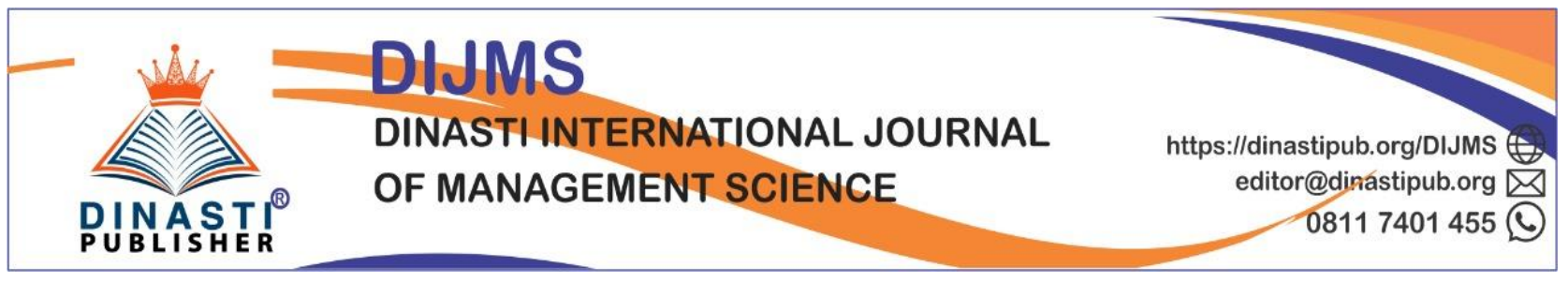

\title{
THE MANAGEMENT OF A TRAINING DEVELOPMENT STRATEGIES TO INCREASE THE COMPETITIVE ADVANTAGE OF LIFE LOCAL INSURANCE COMPANIES
}

\author{
Jazai Tirto Utomo', Sangkala Ruslan² \\ 1) Universitas Mercu Buana, jazai88@yahoo.com \\ 2) Universitas Mercu Buana, dr_ruslan_se@yahoo.com
}

\section{Corresponding Author: Jazai Tirto Utomo}

\begin{abstract}
This study aims to analyze the development of training management for employees and agents as well as a training roadmap model and human resource development in increasing competitive advantage in Local Life Insurance. The paradigm in the implementation of this research uses a qualitative phenomenological paradigm as a reference, pattern and framework that starts from empirical generalizations or empirical generalizations on the growth and development of social reality. ThisXresearchxuses qualitativexmethods with thextype ofXcaseXstudy research. Primary data were obtained from information and factual experiences of informants using structured interviews through In-depth interviews and focus group discussions. The results of the study found that this local life insurance company did not yet have training management and employee development. HRD is not able to formulate employee development patterns. This company needs to conduct a comprehensive evaluation of the occurrence of a vacancy in the management system for employee training and development. The results of the study also show management's neglect when there is a vacancy of the people development function by the company's HRD. Agency Training \& Development already owns and implements Agent training management
\end{abstract}

Keywords: Management and Road Map Training, Training Curriculum, People Development, Agency Training and Development, HRD, Competitive Advantage

\section{INTRODUCTION}

Competition in the life insurance industry in Indonesia affects insurance employees and agents as the company's strategic partners. This competition requires employees and insurance agents to improve their competence, insight, attitude and professionalism so that they have high competitiveness. The competency level of Life Insurance employees and agents in Indonesia must be continuously developed so that they can have international standards. The development and demands of the life insurance industry will be more unique and complex due to the development of financial technology and the digital era of all lines of business including the life 
insurance industry. Employees and life insurance agents who do not improve their abilities will be left behind in the competition and their roles can be replaced by global life insurance human resources who have competitive advantages.

AAJI (Indonesian Life Insurance Association) as the official organization that houses life insurance companies in Indonesia has taken anticipatory steps so that its members remain competitive in facing competition. AAJI is committed to continuing to encourage agent competence by leaving the status of "sales" and has become a profession that assists customers in making financial plans (financial planner). Changes in basic competencies certainly have consequences for paradigm changes and strategic steps in the training and development process.

Some researchers argue that the knowledge and skills of the workforce in the insurance industry are very important for companies to improve their performance, competitiveness and innovation (Dukhan et al. 2017; Madarisa et al. 2017). Successful life insurance companies appear to be investing more in training and development than other companies, where this training and development program will lead to improved organizational performance and results. Deng et al. (2012) emphasized that the success of any training and development will depend on the governance of the insurance company itself.

As a member of AAJI in responding to competition and increasing the capacity of employees and agents, the Life Insurance Company has established a training academy in 2015. The establishment of this training institute for employees and agents or marketers, the company focuses on improving the competence of employees and agents to be more competitive in marketing products. Life insurance and quality services to customers. Employees and agents or marketers are the spearhead of the company in distributing quality products and services to customers, competently they must be reliable and professional resources.

Data on the growth of new partners/insurance agents who were successfully recruited and joined the company during the 2017-2019 period were 3,684 agents, an increase of around $48 \%$ from 2017. Despite the growth in the number of new agents, there is an interesting fact that the total active agents owned by the company are very low, namely as much as $11 \%$ or around 820 people from the total agents owned, and only achieved agent growth of 6\% from 2017.

The above facts as well as the results of the author's limited interviews with several employees emphasize that the slowdown and low ratio of active agents was caused by the Training Center within five years of its establishment. The management, methods, and curriculum of agent training have not been systematically structured. The management training aspect is still limited to benchmarking and best practices from the training system and management of competitor insurance companies. This condition occurs because the Training Center has been prepared reactively in response to the dynamics of the life insurance business competition in Indonesia.

Based on the above explanation, the authors are interested in conducting a study on the strategy of the Training Center in preparing, developing and implementing training and development management with the research theme of the management of a training development strategy to increase the Competitive Advantage of Life Insurance Companies. As a PMDN company, this company has different problems, challenges, culture and business goals, so it 
needs training management and agent development that suits the needs and characteristics of the agent and is different from competitors.

\section{LITERATUTE REVIEW Human Resources as Core Competencies}

The development and implementation of organizational strategy should be based on areas of strength in the organization or core competencies, as the basis for creating a competitive advantage for the organization. According to Robert L. Mathis-John H. Jackson (2012), core competencies are unique abilities that create high value and differentiate an organization from its competitors. Of course, many organizations have stated that their human resources differentiate them from competitors as well as a major determinant of competitive advantage. Studies have also documented that HR practices help create a competitive advantage.

One of the aspects to get the greatest contribution from human resources in an organization is that it should not be done in a perfunctory way and do not develop in the long term. One of the methods used is through human resource activities based on research, best practices, and continuous improvement of human resource capacity. HR management can be an interrelated activity that occurs in an organization.

External forces such as, economic, technological, global, environmental, cultural / geographic, political, and social, significantly influence HR activities and how they are designed, managed and transformed. HR management activities include, Strategic HR Management, Equal Employment Opportunities, Staff, Talent Management and Development, Compensation, Risk Management and Worker Protection, Leadership and Labor Relationships.

\section{Management of Training}

The competitive pressures facing organizations today require that staff knowledge and ideas continue to evolve and that they have the skills and abilities that can deliver results. As organizations compete and change to improve organizational performance, employee and leader training becomes more important than ever. Employees have to adapt to the many changes facing the organization and be trained constantly to maintain and update their abilities. Effective training is an essential component of HR management. Robert L. Mathis, John H. Jackson (2012) defines training management as a process where someone has the capability to help achieve organizational goals.

Training provides employees with specific identifiable knowledge and skills to use in their current jobs. Strategic management training is related to how the organization achieves its organizational goals and has many benefits for the organization. These benefits are, strategic training enables HR and training professionals to engage intensely in business processes, partner with operations managers to help solve problems, and make significant contributions to organizational results, training can also affect organizational competitiveness by assisting in employee retention. One of the reasons that many people remain or leave the organization is training and development opportunities. Employers who invest in the training and development of their employees can increase retention efforts. The way companies organize and structure training affects how employees attend training, which in turn affects the effectiveness of training. Effective training requires the use of a systematic training process. 


\section{Training Category}

Training can be designed to meet a number of objectives and can be classified in various ways. Mandatory and Routine Training, meets various legal requirements mandated and given to all employees. Job/Technical Training, enable employees to do their job well (Product knowledge, processes, technical procedures and customer relations). Interpersonal training and problem- solving, addressing operational and interpersonal problems and seeking to improve organizational working relationships (interpersonal communication, managerial/supervisory skills, and conflict resolution). Career and Development Training, provide a long-term focus on improving individual and organizational capabilities for the future (business practice, executive development, organizational change, leadership)

\section{Training and Organizational Strategy}

Training is a significant HR operational expense for most employers. But it is often viewed as tactical rather than strategic, meaning that training is seen as a short-term activity rather than having a long-term effect on organizational success. Fortunately, an increasing number of companies are recognizing that training must be improved. One survey found that about half of the companies surveyed plan to increase their annual training budget. (Mathis \& Jackson, 2012)

Strategic training related to how an organization achieves its organizational goals can have many organizational benefits. Strategic training enables HR and training professionals to engage directly in business processes, partner with operations managers to help solve their problems, and make significant contributions to organizational results. (Mathis \& Jackson, 2012)

\section{Competitive Advantage and Training}

Many companies recognize that training and human resource development efforts are integral to business success. In a sense, for these companies, training is similar to the "continuous improvement" that some manufacturing companies do. The nature of technological innovation and change is such that if employees are not trained all the time, they may fall behind and the company may become less competitive. (Mathis \& Jackson, 2012) Without ongoing training, organizations may not have staff members with the knowledge, skills and abilities necessary to compete effectively. Training can also influence organizational competitiveness by assisting in employee retention. Employers who invest in the training and development of their employees can increase retention efforts. Training can help achieve specific organizational strategies.

\section{Knowledge Management and Training}

According to Mathis \& Jackson (2012), history has proven that, so far, organizational competitive advantage is only measured in terms of physical capital. However, with the times, "intelligence" has become the raw material that many organizations make and sell through their "knowledge workers." Knowledge management is the way organizations identify and utilize knowledge to make it competitive. It is the art of creating value using the intellectual capital of the organization, which is known to the organization (or, more precisely, the people in the organization). Knowledge management is a conscious effort to get the right knowledge to the right people at the right time so that it can be shared and applied. 


\section{Performance and Training Integration}

Employee performance, training and employee learning must be integrated to be effective, and HR plays an important role in this integration. Organizations seek a more authentic (and therefore more effective) training experience for their employees by using "real" business problems to advance employee learning. The trainer includes everyday business problems as examples of learning, thereby increasing the realism of the exercises and training scenarios. Using real-world situations for practice is another way to combine the lines between training, learning, and job performance. (Mathis \& Jackson, 2012)

\section{Global Strategy and Training}

For a global company, the brightest strategies ever devised won't work unless they have trained employees around the world to execute them. A global view of strategic training is becoming increasingly important as companies build and expand operations around the world. The conclusion of this study is that firms may not remain innovative and strategic leaders for much longer, due to a decline in specialized skilled and technical workers. (Mathis \& Jackson, 2012)

\section{Intercultural Competency Training}

More and more global employers are providing intercultural competency training for their global employees. Intercultural competence combines various human social skills and personality characteristics. There are three components of intercultural competence, namely, Cognitive: What do people know about other cultures? Emotional: How does the person perceive other cultures, and how sensitive is the person to customs and cultures? Behavior: How does the person act in intercultural situations?

Used around the world, especially by companies based in Europe, Culture Assimilation is a programmed learning and training program consisting of short case studies and critical incidents. Case studies illustrate interactions between cultures and potential misconceptions involving foreigners and citizens of host countries.

\section{Training Components}

The training plan allows the organization to identify what is required for employee performance before training begins. It is at this stage that strategic issues are confirmed. Effective training efforts consider the following questions: a) Is there really a need for training? b) Who needs to be trained? c) Who will conduct the training? d) What form or model of training will be carried out? e) How will knowledge be transferred to work? f) How will the training be evaluated?

\section{Training Process}

The way companies organize and structure their training affects the way employees experience training, which in turn affects the effectiveness of training. Effective training requires a systematic training process. The four phases of the process such as, assessment, design, implementation, and evaluation. Using such a process reduces the likelihood that unplanned, uncoordinated and haphazard training efforts will occur. 


\section{Training Needs Analysis}

According to Robert. L. Mathis and John H, Jackson (2012) there are 3 sources of training needs analysis: a) Organizational Analysis. Training and development needs can be identified through analyzes of the organization. As an important part of the organization's strategic HR planning is the identification of the knowledge, skills and abilities that will be needed in the future as jobs and organizations change, both internal and external forces will influence training and must be considered when conducting organizational analysis.

b) Job and Task Analysis. The second way to find out a training needs analysis is through an analysis of the work and tasks performed, by comparing the needs in the job with knowledge. By comparing job requirements with employees' knowledge, skills, and abilities, training needs can be identified.

c) Individual analysis. The third action is to know that the training needs focus on individuals and how they do their jobs. The most common approach to making such individual analyzes is to use job appraisal data. Another way to assess individual training needs is to conduct a survey of employees, both managerial and non-managerial, regarding the training needed.

\section{Design Training}

Once the training objectives have been determined, designing and defining the training design can begin. Training must be designed to match the specific needs assessed. Effective training designs take into account different learning concepts and approaches to training. There are three main considerations when designing training: (1) determining the consistency of learning, (2) understanding different learning styles, and (3) designing training transfers. Each of these elements must be considered in order for the training design to integrate and produce effective learning. (Mathis \& Jackson, 2012)

\section{Training Evaluation}

The purpose of evaluation is to obtain accurate and objective information about a program that has been planned and implemented. This information can be in the form of program implementation process, impact / results achieved, and efficiency.

The results of the evaluation can also be in the form of evaluating the learning program. Several evaluation models include 1) Kirkpatrick's Evaluation Model (Kirkpatrick's Four Levels Evaluation Model), 2) CIPP Evaluation Model (Context, Input, Process, and Product), and 3) Stake Model Evaluation (Model Countenance).

Of these three models, each of them has different characteristics. This study focuses more on Kirkpatrick's Evaluation Model. The evaluation model developed by Kirkpatrick is known as the Kirkpatrick Four Levels Evaluation Model. Kirkpatrick's evaluation of the effectiveness of the training program includes four levels of evaluation, namely: level 1 reaction, level 2 learning, level 3 behavior, and level 4 result.

\section{Theoretical framework}


The preparation of training management is carried out in an integrated manner between the Company's Strategic Management, Operations Division, HRD Department and Agency Distribution Department. After the internal analysis and external analysis are carried out, the training and HR management as well as the supporting system are planned jointly and integrative as illustrated as follows;

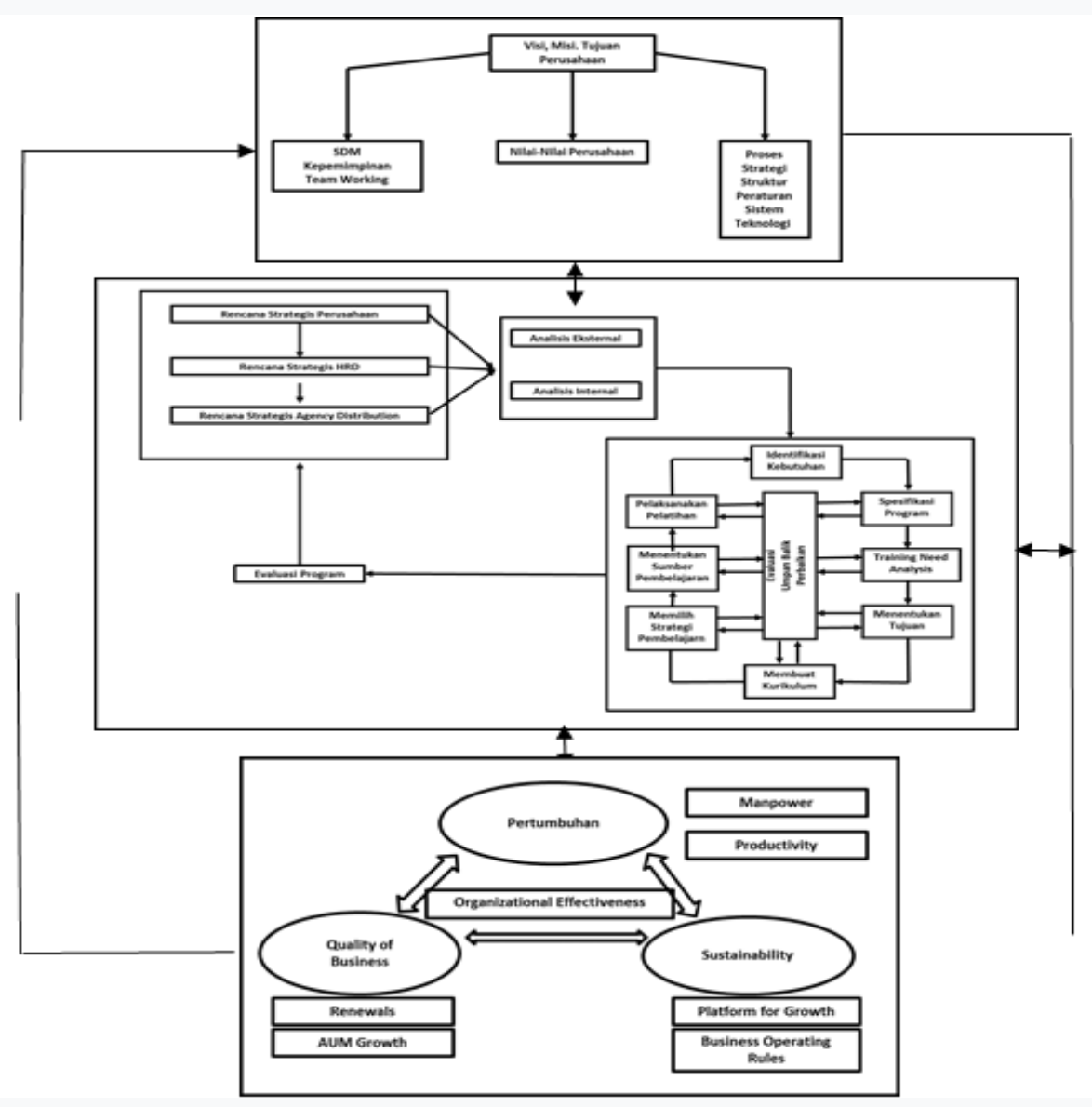

\section{RESEARCH METHOD}

The paradigm in the implementation of this research uses a qualitative phenomenological paradigm as a reference, pattern and framework that departs from empirical generalizes or empirical generalizations of growing and developing social, political and cultural realities. These social realities are described and analyzed in a comprehensive and comparative manner

The research method used is a qualitative method. According to Creswell (2012), qualitative research is a method for exploring and understanding the meaning that some individuals, groups of people and organizations think come from social or humanitarian problems. Thus, a qualitative research method is basically a method of interpreting or interpreting a phenomenon or symptom, both the perpetrator and the product of the action.

This type of research used in this thesis research is a case study. According to Yin (2014), a case study is a method of approach to social science research where in general the approach is 
more appropriate if the main question of a research is "how" or "why". This study will explore primary data from information and factual experiences from informants using structured interviews through In-Depth Interview and Focus Group Discussion.

\section{FINDINGS AND DISCUSSION Research Result}

\section{Structured Interview}

It is carried out by first giving direction to the key informant about the employee training and development model including steps and related targets for each strategic objective. Research participants have a thorough understanding of the design and content of the training management development model and development in the Life Insurance Industry.

a) First Research Question (PP1); Employee Training Policy

The first question designed to be explored by this research is how the policies and strategies undertaken by companies in developing human capital through training and development. The overall findings for the first research question are consistently positive. The main themes found in open coding are presented in table below;

\begin{tabular}{|l|l|}
\hline Participants & Theme \\
\hline Director of Operations & $\begin{array}{l}\text { The company has established a training } \\
\text { and development center }\end{array}$ \\
\hline Marketing Director & $\begin{array}{l}\text { Training Center is a form of company's } \\
\text { attention and focus in improving the } \\
\text { quality of employees and sales force }\end{array}$ \\
\hline Head of HRD & $\begin{array}{l}\text { HRD has not yet described the } \\
\text { company's policy on HR } \\
\text { development } \\
\text { - HRD is still a Cost Center }\end{array}$ \\
\hline Head of Agency & $\begin{array}{l}\text { The company encourages continuous } \\
\text { training of marketers }\end{array}$ \\
\hline Head of Agency Training and Development & $\begin{array}{l}\text { Training academy should be } \\
\text { understood as a company policy that } \\
\text { focuses on HR development }\end{array}$ \\
\hline Team Leaders Agency Force & $\begin{array}{l}\text { The company has made good policies } \\
\text { for the development of agency force }\end{array}$ \\
\hline Employees 1,2,3 & $\begin{array}{l}\text { The company provides opportunities } \\
\text { for training, but HRD does not have } \\
\text { scheduled training }\end{array}$ \\
\hline
\end{tabular}

b) Research Question Two (PP2); Employee Training and Development Management

The second question designed to be explored by this study is the company's ability to structure and develop employee training management the overall findings for study question two are consistently negative. The main themes found in open coding are presented in the following table; 


\begin{tabular}{|l|l|}
\hline Director of Operations & $\begin{array}{l}\text { Does not have training management. } \\
\text { This year the company will partner } \\
\text { with a consultant }\end{array}$ \\
\hline Marketing Director & $\begin{array}{l}\text { Training center do not have employee } \\
\text { training management }\end{array}$ \\
\hline Head of HRD & $\begin{array}{l}\text { Has not made an employee training } \\
\text { road map }\end{array}$ \\
\hline Head of Agency & $\begin{array}{l}\text { Training is only the introduction of the } \\
\text { company to new employees }\end{array}$ \\
\hline Head of Agency Training and Development & $\begin{array}{l}\text { HRD does not have a training system, } \\
\text { the training center only has training } \\
\text { management for marketers, while for } \\
\text { employees there is no }\end{array}$ \\
\hline Team Leaders Agency Force & $\begin{array}{l}\text { Agents are only given basic training } \\
\text { and soft skills }\end{array}$ \\
\hline Employees 1,2,3 & $\begin{array}{l}\text { Employees have never been given } \\
\text { training meaning that HRD does not } \\
\text { have a system }\end{array}$ \\
\hline
\end{tabular}

c) Research Questions Three (PP3); Organizational Structure

The third question designed to be explored by this study is the organizational structure of the person in charge of training and employee development implementation. The overall findings for study questions three are consistently negative. The main themes found in open coding are presented in the following table;

\begin{tabular}{|l|l|}
\hline Participants & Theme \\
\hline Director of Operations & $\begin{array}{l}\text { Training centers that have been } \\
\text { established do not have an effective } \\
\text { organizational structure }\end{array}$ \\
\hline Marketing Director & $\begin{array}{l}\text { There should be restructuring of the } \\
\text { training center for effective training } \\
\text { processes }\end{array}$ \\
\hline Head of HRD & $\begin{array}{l}\text { HRD is not in charge of the training } \\
\text { center as an organization but in a } \\
\text { responsible function. }\end{array}$ \\
\hline Head of Agency Training and Development & $\begin{array}{l}\text { The Agency Division already has its } \\
\text { own agency training and development } \\
\text { department }\end{array}$ \\
\hline Employees 1,2,3 & $\begin{array}{l}\text { The agency training and development } \\
\text { department is not part of the people } \\
\text { development HRD but of the Agency } \\
\text { Distribution }\end{array}$ \\
\hline $\begin{array}{l}\text { HRD does not have people } \\
\text { development }\end{array}$ \\
\hline
\end{tabular}

d) Research Questions four (PP4); Problem Solving Program

The fourth question designed to be explored by this research is the steps that must be taken to address structural problems and management systems for employee training and development. The overall findings for the four research questions are consistently positive. The main themes found in open coding are presented in the following table; 


\begin{tabular}{|l|l|}
\hline Participants & Theme \\
\hline Director of Operations & $\begin{array}{l}\text { HRD must be given full } \\
\text { responsibility and target and } \\
\text { deadline for restructuring training } \\
\text { centers mus have a people } \\
\text { HRD must hasection } \\
\text { development section }\end{array}$ \\
\hline Marketing Director & $\begin{array}{l}\text { HRD should be given tasks and } \\
\text { targets to solve employee } \\
\text { development training problems. } \\
\text { Training centers is focused on } \\
\text { training and developing sales force }\end{array}$ \\
\hline Head of HRD & $\begin{array}{l}\text { HRD must have the courage to make a } \\
\text { breakthrough by forming the People } \\
\text { Development section this year }\end{array}$ \\
\hline Head of Agency & $\begin{array}{l}\text { HRD should not focus on } \\
\text { administrative activities but must } \\
\text { establish a training and employee } \\
\text { development department }\end{array}$ \\
\hline Head of Agency Training and Development & $\begin{array}{l}\text { The agency training and development } \\
\text { department may not be given additional } \\
\text { burdens to carry out HRD people } \\
\text { development functions, but a new } \\
\text { training department is formed under } \\
\text { HRD }\end{array}$ \\
\hline Employees 1,2,3 & $\begin{array}{l}\text { HRD must immediately change and } \\
\text { focus on employee training }\end{array}$ \\
\hline
\end{tabular}

\section{Focus Group Discussion (FGD) with Agency Division}

To explore more about training programs and development of agency force partners, a focused or thematic discussion was held with the ranks of the Agency Division. Present as FGD participants were the Head of Agency Division, Head of Agency Training \& Development, Agency Leader Jakarta and Head of Agency Support. The theme of the discussion is the deepening of training management for the Agency Force, exploration of steps that must be taken to overcome obstacles in the process of implementing training and developing Agency Force. The overall findings for this FGD are consistently positive. The main themes found in open coding are presented in the following table;

\begin{tabular}{|c|c|}
\hline Participants & Theme \\
\hline Head of Agency Division & $\begin{array}{l}\text { - Make policies based on the vision and targets } \\
\text { of the company. } \\
2019 \text { has a growth target of premium and } \\
\text { manpower. Divisional policies improve } \\
\text { performance through the Faster, Better and } \\
\text { Stronger programs. } \\
\text { - All components in the Agency Division are } \\
\text { directed to have the same vision and mission. } \\
\text { - Placing Business Development Agency in } \\
\text { five areas }\end{array}$ \\
\hline
\end{tabular}




\begin{tabular}{|c|c|}
\hline & - Reasonable logistical support \\
\hline Head of Agency Support & $\begin{array}{l}\text { - Provide administrative and technical services } \\
\text { to all Agency Staff and Agency Force } \\
\text { effectively and quickly }\end{array}$ \\
\hline $\begin{array}{l}\text { Head of Agency Training and } \\
\text { Development }\end{array}$ & $\begin{array}{l}\text { - Evaluate and develop training management } \\
\text { - Placing trainers in each area } \\
\text { - Adding soft skills training and competency in } \\
\text { recruiting and selling }\end{array}$ \\
\hline $\begin{array}{l}\text { Agency Business Development } \\
\text { Specialist }\end{array}$ & $\begin{array}{l}\text { - Focus on the coaching process and Agency } \\
\text { Force development } \\
\text { - Improve the competence of the Agency Force } \\
\text { in recruitment and sales } \\
\text { - Assistance to agents and teams. }\end{array}$ \\
\hline Agency Leaders & $\begin{array}{l}\text { - Focus on recruitment and sales activities } \\
\text { - Increase participation in training }\end{array}$ \\
\hline
\end{tabular}

\section{Data Analysis}

1. Company Training Management SWOT Analysis

a. Strength Factor

- Policy and management commitment to improve employee competence

- Has a Training and Development Institute

- Has the structure and human resources to manage the training and development of Marketing Personnel Partners

b. Weakness Factor

- HRD does not have a structure and HR that focuses on managing employee training and development

- HRD does not have a strategic plan for management of training and employee development

- HRD does not yet have training and development technology

c. Opportunity Factor

- Government policy on minimum competency standards for insurance companies

- Life Insurance Association policy on professional certification for marketers

d. Threat Factors

- Competitors continue to improve management and employee training and development technology

- The migration of insurance experts is very high

2. Internal Element Analysis

a. Aspects of Company Policy

The company has policies and strategies for training and human resource development through management commitment to improve the quality of human resources for employees and partners in order to have high professionalism and an ethos that promotes service excellence.

From the research findings, it can be seen that all the resource persons emphasized that management focuses on this. This commitment is also proven by the 
establishment of the Employee Training and Development Institute and partners in 2015.

b. System Aspects

The policies that have been initiated by the company have not been able to be implemented practically in the form of training management. From the results of the interview above, it can be seen that HR and HRD managerial problems are the main inhibiting factors for companies to have a management system for employee training and development. This problem is exacerbated by the neglect by top management to date. The Training and Development Institute that has been established turns out to be only focused on training agents and leaders

The positive aspect that was discovered was the Agency Division's ability to create a Training and Development Road Map for agents and leaders. From the existing data, it can be seen that the training and development management compiled does not have a complete dictionary of agent and leaders' competencies, the TNA method, the evaluation method and the learning method.

c. Structural Aspects

HRD does not have an organization that is responsible for people development. The Head of HRD is unable to take the initiative to form an organization that is tasked with performing employee training and development functions.

The agency division has a clearer and tidier structure by forming the agency training and development department. This department is fully responsible for training and development activities.

d. HR Aspects

The company does not yet have special human resources and is responsible for managing employee training and development. To carry out agency force training and development, the Company has five trainers, five as business development staff and ten people in agency support.

e. Best practice strategies are used by training and development agencies in preparing training management. However, this is not followed by conducting a study of the company's internal and external aspects.

f. The training for Agents and Leaders is not in accordance with the existing training road map. This is due to the low participation of agents and low active agents, which are only $11 \%$ of the total agents owned by the company.

g. The monitoring, controlling and evaluation system for the Agency Force's training and development management has not been well documented and systematic in the form of a data base for the implementation program. Training. Training evaluation is carried out limited to providing feedback during training.

\section{Discussion \\ Revitalization of HRD Function}


The development of the corporate environment, uncertainty, complexity and intra organizational conflict develops mainly due to a large working area. The intense competition in the global era with the main characteristic of technological development has resulted in pressure from outside the organization as well as from within the need to be managed equally well. Organizations that continue to maintain their external competitiveness, among others, rely on human resource development plans. The parties involved in management need to be accommodated in their thoughts in participation and development efforts.

The competitive pressures facing the Company today require that the knowledge and ideas of staff continue to evolve and that they have the skills and abilities that can deliver results. As companies compete and change to improve organizational performance, employee and partner training is more important than ever. Employees must adapt to the many changes facing the company and be continuously trained to maintain and update their abilities. Also, managers must have training and development to enhance their managerial and leadership skills and abilities. Effective training is an essential component of HR management.

The company's strategy to increase the capacity and capability of employees starts from evaluating the functions and roles of HRD. Management must measure and determine the competency model needed to clarify job expectations, productivity, and support adjustment to change. At the manager level, it needs to be evaluated, namely emotional intelligence competence (EIC) which includes: achievement, affiliation, power, management, cognitive, and personal effectiveness, to summarize and map the competence of HR managers.

Competence is often associated with a position that is pursued (nurture), while talent (talent) is natural (nature). These efforts are first the task of every HR manager. This is because this managerial competence animates the department it leads. Managerial competence is not only owned by the HR department, but all managers who have subordinates.

The matrix competency model can also be used to review HRD in organizations. According to the Ban ff Center Competency Model consists of six competencies: self-mastery, fluttering, sense making, design of intelligent action, aligning people to action, and adaptive learning (adaptive learning). Each of these six competencies consists of the four factors that compose them. First, self-mastery competencies include self-awareness, self-development, selfdiscipline, and authority to act on oneself. Second, featuring competence is the ability to see the future (foresight), act strategically, communication (out / in communication), and purpose (intention). The third competency, meaning is built by the ability to think interactively, disciplined inquiry, communication (in / out communication), and pattern recognition. Whereas fourth, the competence of smart action design includes: perspective, sensitivity, stabilizing and destabilizing strategies, and commitment. The fifth competency factor, aligning people to act includes: creative capacity, engaging others (engaging others), understanding others (understanding others), and attracting needed sources (attracting resources). Adaptive learning competency factors: reflective learning (reflexive learning), creating space for generalizations, recognizing challenges, and leveraging knowledge for the future. (Gary Dressler, 2015)

Evaluation of HRD competencies including hard competencies and soft competencies has also become a focus for improvement at the individual, team, and company level in line with the development of the organization's environment. 
Management must ensure the HR leader (HRD leader) as part of a strategic positioned system builds a leadership system through coaching, mentoring, stewardship, and learning collaboration. Leaders with human capital competencies respond to changes in the organizational environment through the creation of strategic added value according to customer expectations to get superior performance through individual competitiveness in teams, organizations, industries so that they become brands at the regional and global levels.

HRD as an individual HR professional must be able to build a system of conscience by increasing the competitiveness and attractiveness of individuals as role models with regional and global standards. Management must ensure that HRD has a superior performance work system, produces an active altruistic attitude and contributes to the business optimally. The four levels of credibility (reactive, inactive, proactive, and proactive) drive the spirit of joy (joy and enjoy). Internal learning based on the strength of these talents responds to problematic situations into personal efficacy and organizational efficacy.

Individual HR professionals in the HR department, through a superior performance work system integrated vertically with a strategic positioning system through four levels of credible pro activism. Thus, the HR department can build all-round human capital competency systems in four dimensions as: capability builders, HR innovators and integrators, champions of change, colonic and holistic technology proponents. Organizational competitiveness is built through a work system culture of superior performance as one of the core competencies.

\section{Preparation of Training Management}

Steps that management can take is to force or give instructions with a time limit and consequences of HRD to immediately make training management. This step requires consistent and ongoing monitoring and evaluation of management. Researchers agree with the theory of Robert L. Mathis, John H. Jackson (2012) which states that the way companies organize and organize training affects how employees participate in training, which in turn affects the effectiveness of training. Effective training requires the use of a systematic training process, namely;

1. The first process is an assessment consisting of an analysis of training needs and identification of training objectives and criteria. Assessment is carried out at the beginning before conducting training to find or identify what abilities employees need in order to support organizational needs. Effective training efforts consider the following questions:

a. Is there really a need for training?

b. Who needs to be trained?

c. Who will conduct the training?

d. What form or model of training will be carried out?

e. How will knowledge be transferred to work?

f. How will the training be evaluated?

After identifying what training the employees need, the next step is to determine the objectives of each training that will be carried out.

2. The second process is design which consists of selecting training methods and training content. At this stage, the methods and content of the training will be determined and adjusted to the need's assessment analysis. 
3. The third process is delivery which consists of schedule, implementation and monitoring of training. This stage is a series of activities for implementing training programs in accordance with the results of the design and monitoring of the course of the training.

4. The last training process is evaluation, which is measuring the results of the training and comparing it with the stated objectives. Whether the training was running successfully and according to the objectives to be achieved or not.

Training can be designed to meet a number of objectives and can be classified in various ways. Some of the training groupings are as follows:

a. Mandatory and Routine Training, meets various legal requirements mandated and given to all employees

b. Job / Technical Training

c. Enable employees to do their job well (Product knowledge, processes, technical procedures and customer relations).

d. Interpersonal Training and Problem Solving, addressing operational and interpersonal problems and seeking to improve organizational working relationships (interpersonal communication, managerial / supervisory skills, and conflict resolution).

e. Career and development training. Provides a long-term focus on improving individual and organizational capabilities for the future (business practice, executive development, organizational change, leadership).

Other factors that must be the foundation and foundation for the preparation of training management in life insurance companies are;

a. The company's strategic goals, covering the vision, mission and targets

b. The expected business processes include strategy, structure, rules of the game (company regulations), systems and technology

c. Human resources, related to self-awareness (self-awareness), leadership spirit and team working.

d. The principle that is carried out consists of the unity of language, the unity of values and the unity of language (common vision, common values and common language)

e. Participation, awareness and seriousness when participating in activities

\section{Agent Training and Development}

Agency Division, is obliged to ensure that the training and agent development process has met the nine basic aspects of the agency development cycle, namely vision, mission, targets, main values, productivity, recruitment, selection, training and agency environment.

\section{CONCLUSIONS AND SUGGESTIONS Conclusion}

a) This local life insurance company does not yet have training and employee development management.

b) The management of this company needs to conduct a thorough evaluation of the absence of a training and employee development management system. 
c) The results of the study also show the management's neglect when there is a vacancy of the people development function by the company's HRD.

d) The Training \& Development Agency already owns and implements Agent training management

\section{Suggestion}

a) The management of local life insurance company Life must immediately take strategic steps to restructure and re-actualize training centers as an Employee Training and Development Institute

b) HRD must immediately take strategic steps by forming a people development organization, and immediately arrange training management that can improve employee competence.

c) Further qualitative research on the financial performance of insurance companies that do not have management training and employee development needs further research.

\section{REFERENCES}

AAJI (Asosiasi Asuransi Jiwa Indonesia).2019. https://www.aaji.or.id/RuangMedia/

AAMAI (Asosiasi Asuransi Jiwa Indonesia). 2019. https://aamai.or.id/web/academicsdepartments/literature/

Ahmad, N. M. N. N., A. Nawawi, and A. S. A. P. Salin. 2016. The relationship between human capital and Director's Remuneration of Malaysian Public Listed Companies. International Journal of Business andSociety 17 (2): 347.

Armstrong, M., and S. Taylor. 2014. Armstrong's Handbook of Human Resource Management Practice. Kogan Page Publishers.

Bowers, A. J. 2017. Quantitative research methods training in education leadership and administration preparation programs as disciplined inquiry for building school improvement capacity. Journal of Research on Leadership Education 12 (1): 72-96.

Creswell, John W. 2015. Penelitian Kualitatif \& Desain Riset. Yogyakarta: Pustaka Pelajar.

Dhal, Manorajan. 2014. A Qualitative Study of Training Effectiveness. https://www.iimk.ac.in/websiteadmin/FacultyPublications/Working\%20Papers/149abs.pdf

Dukhan, N. R., N. Mohamad, and A. B. Ali. 2017. Factors affecting on the employees' performance study

Deng, Z., P. S. Hofman, and A. Newman. 2012. Ownership concentration and product innovation in Chinese private SMEs. Asia Pacific Journal Management 30: 717-734

Gary Dessler. 2015, Human Resource Management, Edinburg London: Pearson Education 
ltd., Madarisa, F., M. Noer, Asmawi, and Jafrinur. 2017. Collaborative training to improve beef cattle farmers' technical competency in West Pasaman District. International Journal of Agricultural Sciences 1

Mathis, Robert L. dan John H. Jackson. 2012. Manajemen Sumber Daya Manusia, Edisi Pertama Salemba Empat, Jakarta

Messah, Omboi Bernard. 2018. Factors Influencing Agents Retention In Insurance Industry: A Survey Of Selected Insurance Companies In Nairobi, Journal of Economics and Sustainable Development ISSN 2222-1700 (Paper) ISSN 2222-2855 (Online) Vol.2, No.3, www.iiste.org

Moleong, Lexy J. (2012). Metodologi Penelitian Kualitatif. Bandung, PT Remaja Rosdakarya.

Oluwaseun, Oduwusi Oyewole.2018. Employee Training and Development as A Model for Organizational Success, International Journal of Engineering Technologies and Management Research, Http://www.ijetmr.com

Rahardjo, Mudjia. 2010. Nalar Dasar Penelitian Kualitatif dan Kuantitatif. www.uinmalang.ac.id

Shahrizal Badlishah. 2016. Training Effectiveness In Continuing Professional Development Program for Insurance Agents, http://ejournal.uum.edu.my/index.php/jtom/article/view/10050

Sudhakar, Basariya. 2017. Perspectives and The Factors Influencing Effectiveness Of Training And Development On Employees' Performance, International Journal of Civil Engineering and Technology (IJCIET) Volume 8, Issue 9, September 2017, pp. 135-141

Ulrich, Dave, Jon Younger, Wayne Brockbank, dan Mike Ulrich. 2012. HR Talent and the New HR Competencies Competency, Washington D.C.: SHRM

Yin, Robert K 2014. Case Study Research Design and Methods (5th Ed.). Thousand Oaks, CA: Sage. 282 pages. 